\title{
Prevalence and antibiogram of coagulase negative Staphylococci in bioaerosols from different indoors of a university in India
}

\author{
Himani Kumari, Trina Chakraborti, Madhuri Singh ${ }^{*}$, Maneet Kumar Chakrawarti and Kasturi Mukhopadhyay ${ }^{*}$
}

\begin{abstract}
Background: Staphylococci species are the major constituents of infectious bioaerosols, particularly methicillinresistant Staphylococci (MRS) have serious health impacts. Here, the bacterial burden was quantified, especially prevalence of MRS in bioaerosols collected from indoors of Dr. B.R. Ambedkar Central Library (DBRACL) and Central Laboratory Animal Resources (CLAR) of Jawaharlal Nehru University, New Delhi, India. Air samplings from DBRACL and CLAR were done using the settle plate method and SKC biosampler, respectively.

Results: This study showed a maximum $6757 \mathrm{CFU} / \mathrm{m}^{2} / \mathrm{hr}$ of bacterial load in the DBRACL reading room, while unacceptable bacterial loads (> $1000 \mathrm{CFU} / \mathrm{m}^{3}$ of air) at different sites of CLAR. Further, at both the sampling sites the predominance of coagulase negative Staphylococci (CNS) was observed. A total 22 and 35 Staphylococci isolates were isolated from DBRACL and CLAR bioaerosols, respectively. Majority (16/22) of the Staphylococcal isolates from DBRACL belonged to human-associated Staphylococci where S. haemolyticus (5/22) was the most dominating species. However, in CLAR facility centre, animal-associated Staphylococci (19/35) were dominating, where S. xylosus $(12 / 35)$ was the most dominating species. Further, antibiotic sensitivity tests revealed $41 \%$ MRS and $73 \%$ multidrug resistant (MDR) among airborne Staphylococci from DBRACL indoor bioaerosols. Similarly, in CLAR facility, approximately, 66\% Staphylococci isolates were methicillin resistant, out of which 2 isolates showed high MIC value $\geq 16 \mu \mathrm{g} / \mathrm{mL}$. Further, we confirmed the presence of $49 \%$ multidrug resistant Staphylococci in the indoor air of CLAR facility.

Conclusions: This study suggested that the exposure of workers and students in CLAR to such a high concentration of drug-resistant Staphylococci should not be undermined, as these bacterial concentrations are the direct representative of inhalable particulate matter $\left(\mathrm{PM}_{2.5}\right)$ as per collection procedure. Simultaneously, passive sampling from DBRACL assessed the risks due to microbial contamination in particle agglomerates, which may deposit on the crucial surfaces such as wounds/ cuts or on the frequently used items.
\end{abstract}

Keywords: Bioaerosol, Infectious bioaerosol, Staphylococci, CNS, Methicillin-resistance, Multi-drug resistance

\footnotetext{
*Correspondence: chauhan.madhuri@gmail.com; kasturim@mail.jnu.ac.in; kasturi26@hotmail.com

School of Environmental Sciences, Jawaharlal Nehru University, New Delhi 110067, India
}

(c) The Author(s). 2020 Open Access This article is licensed under a Creative Commons Attribution 4.0 International License, which permits use, sharing, adaptation, distribution and reproduction in any medium or format, as long as you give appropriate credit to the original author(s) and the source, provide a link to the Creative Commons licence, and indicate if changes were made. The images or other third party material in this article are included in the article's Creative Commons licence, unless indicated otherwise in a credit line to the material. If material is not included in the article's Creative Commons licence and your intended use is not permitted by statutory regulation or exceeds the permitted use, you will need to obtain permission directly from the copyright holder. To view a copy of this licence, visit http://creativecommons.org/licenses/by/4.0/. The Creative Commons Public Domain Dedication waiver (http://creativecommons.org/publicdomain/zero/1.0/) applies to the data made available in this article, unless otherwise stated in a credit line to the data. 


\section{Background}

The increasing microbiological air pollution that is caused by the contaminated bioaerosols, has huge impact on the human health $[1,2]$. Both the culturable and non-culturable bioaerosols can act as an important reservoir for antimicrobial resistance genes (ARG) by virtue of their free mobility, consequently putting people with compromised immunity at risk of catching infections [3-5]. In particular, the microorganisms present in indoor bioaerosols are the direct threat to human health as they can cause infections with prolonged exposure $[6,7]$. Therefore, checking the bacterial burden in indoor air has been frequently practiced in the hospital settings in order to mitigate the hospital-associated infections (HAIs) $[3,5,6]$. However, with the prevailing airborne antimicrobial resistance (AMR) and ARG in different environmental settings $[4,8,9]$, the quantification of airborne indoor microbiome is a need of the present moment. Among airborne culturable bacteria, Staphylococcus species are the most common both in residential [10] as well as in hospital indoors bioaerosols [6, 11]. Staphylococci species are broadly divided into two groups: coagulase-positive Staphylococci (CPS such as $S$. aureus) and coagulasenegative Staphylococci (CNS such as $S$. epidermidis). Of total 47 Staphylococcal species, 7 (1 CPS and 6 CNS) belong to human-associated Staphylococci, which colonize specifically in humans, these are; S. aureus, S. capitis, S. caprae, $S$. epidermidis, S. haemolyticus, S. hominis, S. lugdunensis, S. saprophyticus, and S. warneri [12]. Among them, S. aureus is a leading cause of infections such as endocarditis, bacteremia, septic-shock. While S. epidermidis, S. haemolyticus and $S$. saprophyticus are CNS type, and are the most prevalent infective agents in hospital-acquired infections such as urinary tract infection (UTI) and indwelling medical device-associated bacteremia $[12,13]$. Moreover, S. aureus is the most common human commensal and methicillin resistant S. aureus (MRSA) is commonly implicated in both hospital-acquired as well as in community-acquired infections Recently, CNSs are also reported as the most common bacterial pathogens in the hospital air [14-16]. Moreover, it is very difficult to eradicate CNS infections due to their species diversity leading to different anti-biograms and minimum inhibitory concentration (MIC) breakpoints $[12,17]$.

Previously the CNSs were considered as harmless bacteria but over the last few decades, treatment of CNS infections has become increasingly challenging due to the increasing number of methicillin resistant strains with reduced susceptibility to glycopeptides and other old and new antibiotics [18-20]. It was observed from previous studies that methicillin resistant CNS (MR-CNS) were dominating over methicillin-resistant S. aureus (MRSA) among clinical Staphylococci strains, the scenario continues till today $[14,19,20]$.

Previous research regarding the prevalence of airborne total culturable bacteria in the household indoors has demonstrated that Staphylococci is dominant among airborne bacteria, and $66 \%$ of households were positive for MRSA with 2-80 CFU $/ \mathrm{m}^{3}[10,21]$. Some confined environments in the university such as library and laboratory are the potential sites for the indoor bioaerosols sampling in order to evaluate the air quality inhaled by the students and staff residing there [22, 23]. Therefore, the present study was aimed to measure the total bacterial load in the bioaerosols of Dr. B.R. Ambedkar Central Library (DBRACL) and Central Laboratory Animal Resources (CLAR) environments in Jawaharlal Nehru University with special reference to airborne Staphylococci concentration. Further, the characterization of species diversity among collected Staphylococci was performed using both biochemical and molecular methods, followed by their antibiotic sensitivity profiling against commonly used anti-staphylococcal agents to estimate their multi-drug resistance level.

\section{Results}

Concentration of airborne bacteria and Staphylococci in Dr. B.R. Ambedkar central library (DBRACL) and central laboratory animal resources (CLAR)

In DBRACL the climatic conditions, temperature and relative humidity ranged between $27^{\circ} \mathrm{C}-30.7^{\circ} \mathrm{C}$ and $30.3-59 \%$, respectively and the number of students in the reading room were varying from 96 to 112 during the entire course of air sampling. Overall, the bacterial counting was ranged from 314 to $6757 \mathrm{CFU} / \mathrm{m}^{2} / \mathrm{h}$ in DBRACL. Except for the reading room (on the ground floor), data from all other floors show low bacterial load (Fig. 1a). Total bacterial load in the reading room were found to be maximum (6756.76 $\mathrm{CFU} / \mathrm{m}^{2} / \mathrm{hr}$ ) during the monsoon season. However, bacterial load in the outdoor environment was extremely high i.e., $50,597 \mathrm{CFU} / \mathrm{m}^{2} / \mathrm{hr}, 33,312 \mathrm{CFU} / \mathrm{m}^{2} /$ $\mathrm{hr}$ and $12884 \mathrm{CFU} / \mathrm{m}^{2} / \mathrm{hr}$ during the pre-monsoon, monsoon and post-monsoon, respectively (Fig. 1a). Therefore, further analyses were performed on the samples from Library reading room only.

Next, we characterized the bacterial load from reading room as Gram positive bacteria (GPB) and Gram negative bacteria (GNB) and compared their contribution in the total bacterial load (Fig. 1b). The data showed that the number of GPB was higher than that of GNB (Fig. 1b) in all seasons. As illustrated in the Fig. 1b, similar to total bacterial load, total GPB were also higher during the monsoon than pre-monsoon and post-monsoon. For example, in monsoon season GPB load was $5185.42 \mathrm{CFU} / \mathrm{m}^{2} / \mathrm{hr}$, whereas in pre-monsoon and post-monsoon it was 3142.68 and $3771.21 \mathrm{CFU} / \mathrm{m}^{2} / \mathrm{hr}$, respectively. In contrast, total GNB were higher during post-monsoon (1728.47 $\mathrm{CFU} / \mathrm{m}^{2} / \mathrm{hr}$ ) than pre-monsoon and monsoon (Fig. 1b). Like GPB, the Staphylococcal load in the reading room 
(a)

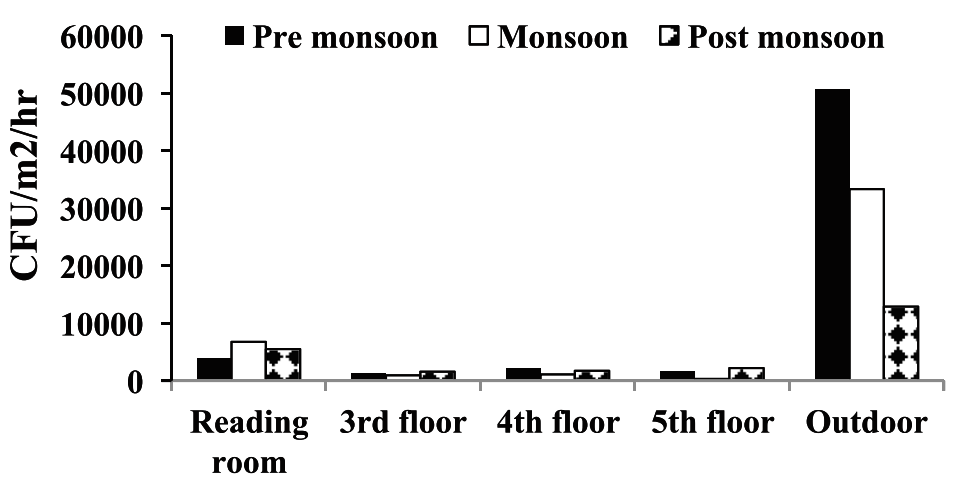

(b)

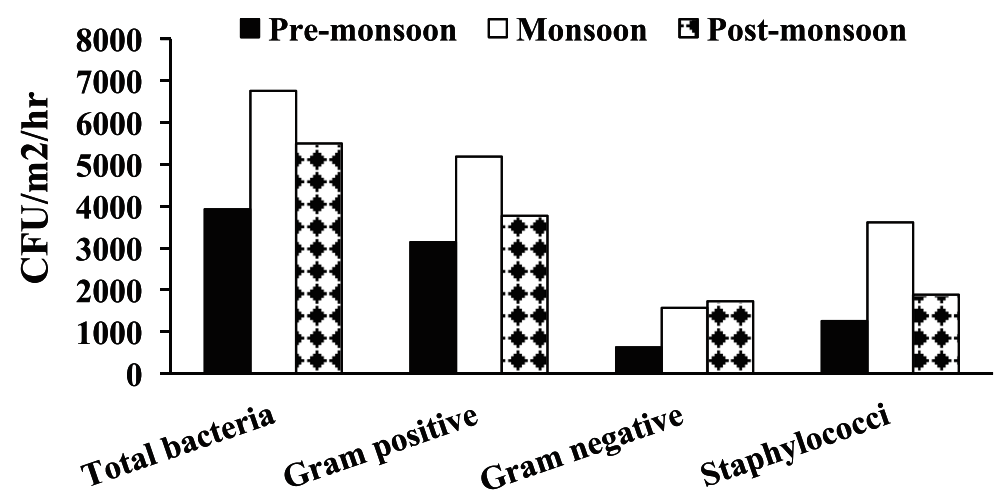

Fig. 1 Bacterial loads in Dr. B.R. Ambedkar Central Library (DBRACL) Bioaerosols at different season: a Total bacterial load (CFU/m²/hr) in different rooms of the DBRACL; $\mathbf{b}$ Total bacteria, Gram positive bacteria, Gram negative bacteria and total Staphylococci in pre-monsoon, monsoon and post-monsoon in DBRACL reading room

was found to be the maximum during monsoon sampling that was $3614.08 \mathrm{CFU} / \mathrm{m}^{2} / \mathrm{hr}$ (Fig. 1b). Since, the bacterial and staphylococcal load was observed maximum during monsoon in the university library, further, this study was extended to determine the bacterial and Staphylococci load in the indoor air collected from university CLAR during monsoon season.

A total load of culturable bacteria and Staphylococci was also very high in the CLAR indoors. A maximum total bacterial concentration was $6360 \mathrm{CFU} / \mathrm{m}^{3}$ in (Fig. 2a) in mice breeding room whereas Fig. 2b showed a maximum $5867 \mathrm{CFU} / \mathrm{m}^{3}$ airborne Staphylococcal concentration in the corridor near to the office. The minimum airborne total bacterial $\left(1173 \mathrm{CFU} / \mathrm{m}^{3}\right)$ and staphylococcal concentration $\left(213 \mathrm{CFU} / \mathrm{m}^{3}\right)$ was found in the rabbit room.

\section{Species diversity of airborne Staphylococci}

A total of 22 Staphylococci strains were isolated from DBRACL reading room during this study. All of them were detected as CNSs by several biochemical tests as described in methods section. These 22 airborne Staphylococci from DBRACL were assigned to eight species of Staphylococci- S. haemolyticus (5/22), S. cohnii (4/22), S. hominis (4/22), S. epidermidis (1/22), S. warneri (1/22), S. saprophyticus (1/22), S. xylosus (4/22) and S. lentus $(2 / 22)$. Next, these staphylococcal isolates $(16$ out of 22) were characterized and confirmed by multiplex PCR [24], as well as by API Staph test [25] (Table 1 and Fig. 3a). The data revealed the dominance of human associated Staphylococci species (16/22 i.e., 72.7\%) among these 22 CNSs (Fig. 3a), while the animal associated Staphylococcus species were only $27.2 \%$ (Fig. 3a). Moreover, S. haemolyticus $(22.72 \%)$ was the most prevalent among human associated Staphylococci, while $S$. xylosus (18.18\%) was the most prevalent among animal associated Staphylococci (Fig. 3a).

In the university CLAR facility, 43 airborne coccus bacteria were obtained and among them 35 isolates were identified as Staphylococci. Out of 35 isolates of Staphylococci, 33 isolates were identified as CNS and 2 were as CPS i.e. S. aureus. These 35 staphylococcal isolates belonged to eight different species of Staphylococcus, namely; S. xylosus (12/35), S. lentus (4/35), S. sciuri (3/35), S. hominis (5/35), S. capitis (4/35), S. epidermidis $(4 / 35), \quad S$. aureus $(2 / 35)$ and $S$. warneri $(1 / 35)$ as 


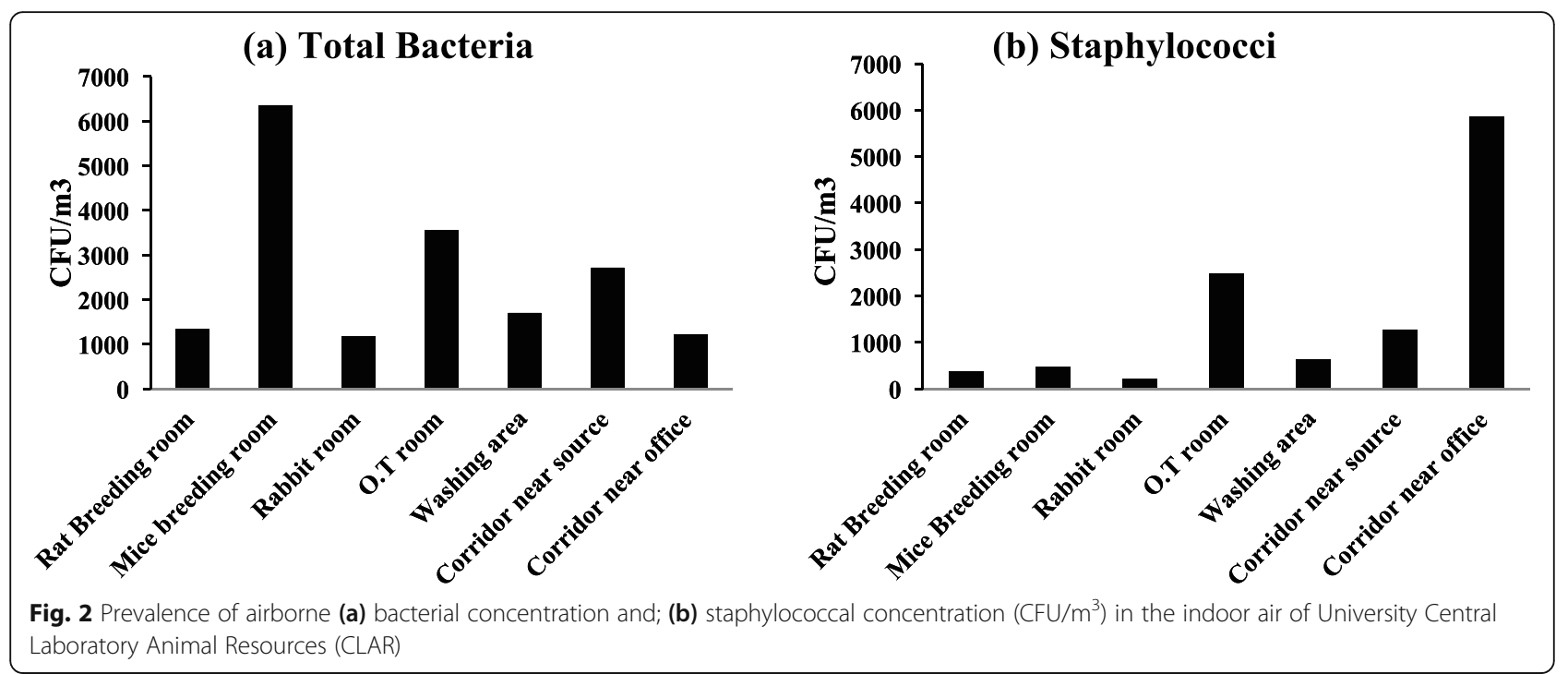

presented in Table 1 (Fig. 3b). In sharp contrast to DBRACL, animal-associated Staphylococci (19/35) were in the majority among CLAR airborne staphylococcal isolates (Fig. 3b). Further, among detected animalassociated Staphylococci isolates, S. xylosus (35\%) was the dominant species, while among human-associated Staphylococci isolates, S. hominis (14\%) was the dominant species (Fig. 3b).
Prevalence of methicillin-resistant Staphylococci in the indoor bioaerosols

Minimum inhibitory concentration (MIC) value of oxacillin of each staphylococcal isolate was determined by broth micro-dilution assay. According to CLSI interpretative criteria, $S$. aureus is considered as MRSA if oxacillin MIC is $\geq 4 \mu \mathrm{g} / \mathrm{mL}$, CNS is considered as MR-CNS if MIC for oxacillin is $\geq 0.5 \mu \mathrm{g} / \mathrm{mL}$ [26] .

Table 1 Minimum inhibitory concentrations (MIC) of oxacillin $(\mu \mathrm{g} / \mathrm{mL})$ against staphylococcal strains isolated from DBRACL and CLAR bioaerosols

\begin{tabular}{|c|c|c|c|c|c|}
\hline \multirow{2}{*}{$\begin{array}{l}\text { Sampling } \\
\text { site }\end{array}$} & \multirow[t]{2}{*}{ Staphylococci isolates } & & \multirow{2}{*}{$\begin{array}{l}\text { MIC of } \\
\text { Oxacillin } \\
(\mu \mathrm{g} / \mathrm{mL})\end{array}$} & \multicolumn{2}{|l|}{ Susceptibility $^{a}$} \\
\hline & & & & Susceptible (\%) & Resistance (\%) \\
\hline \multirow[t]{8}{*}{ DBRACL } & Human associated & S. haemolyticus ( $n=5$ ) & $<0.5-4$ & $3(60)$ & $2(40)$ \\
\hline & & S. cohnii $(n=4)$ & $<0.5-2$ & $1(25)$ & $3(75)$ \\
\hline & & S. hominis $(n=4)$ & $<0.5-16$ & $3(75)$ & $1(25)$ \\
\hline & & S. epidermidis $(n=1)$ & $<0.5$ & $1(100)$ & $0(0)$ \\
\hline & & S. warneri $(n=1)$ & $<0.5$ & $1(100)$ & $0(0)$ \\
\hline & & S. saprophyticus ( $n=1$ ) & 1 & $0(0)$ & $1(100)$ \\
\hline & Animal associated & S. xylosus $(n=4)$ & $<0.5-1$ & $2(50)$ & $2(50)$ \\
\hline & & S. lentus ( $n=2)$ & $<0.5$ & $1(50)$ & $1(50)$ \\
\hline \multirow[t]{8}{*}{ CLAR } & Human associated & S. hominis $(n=5)$ & $1-8$ & $0(0)$ & $5(100)$ \\
\hline & & S. capitis $(n=4)$ & $<0.5-1$ & $2(50)$ & $2(50)$ \\
\hline & & S. epidermidis ( $n=4)$ & $<0.5-8$ & $2(50)$ & $2(50)$ \\
\hline & & S. aureus $(n=2)$ & $1-8$ & $1(50)$ & $1(50)$ \\
\hline & & S. warneri $(n=1)$ & 1 & $0(0)$ & $1(100)$ \\
\hline & Animal associated & S. xylosus ( $n=12$ ) & $<0.5-32$ & $4(33.3)$ & $8(66.7)$ \\
\hline & & S. lentus $(n=4)$ & $<0.5-1$ & $3(75)$ & $1(25)$ \\
\hline & & S. sciuri $(n=3)$ & 1 & $0(0)$ & $3(100)$ \\
\hline
\end{tabular}

\footnotetext{
${ }^{a}$ For CNS: Susceptible (MIC $\leq 0.25 \mu \mathrm{g} / \mathrm{mL}$ ); Resistant (MIC $\geq 0.5 \mu \mathrm{g} / \mathrm{mL}$ ) and For S. aureus: Susceptible (MIC $\leq 2 \mu \mathrm{g} / \mathrm{mL}$ ); Resistant (MIC $\geq 4 \mu \mathrm{g} / \mathrm{mL}$ )
} 


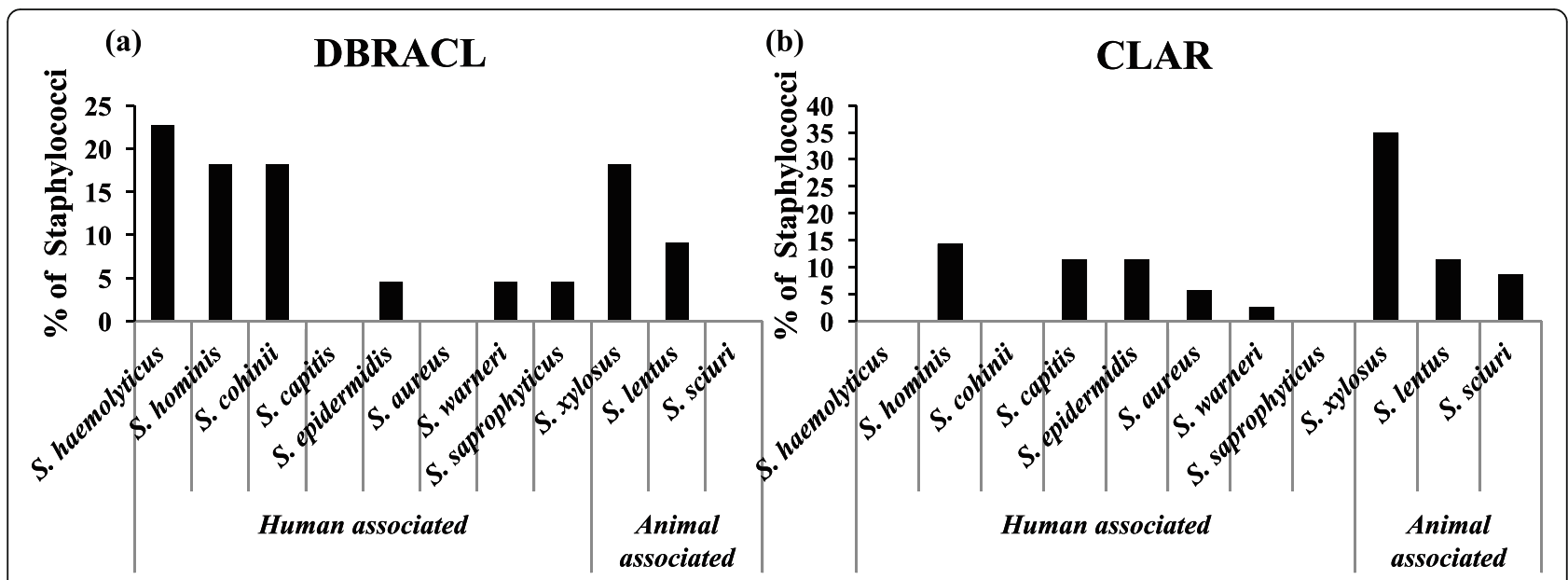

Fig. 3 Prevalence of human-associated Staphylococci and animal-associated staphylococci in the University (a) DBRACL and (b) CLAR bioaerosols samples

In DBRACL, MIC values of oxacillin were obtained $\leq 0.25 \mu \mathrm{g} / \mathrm{mL}$ for $13 \mathrm{CNS}$ isolates, $0.5-2 \mu \mathrm{g} / \mathrm{mL}$ for 7 isolates and $4-16 \mu \mathrm{g} / \mathrm{mL}$ for 2 isolates (Table 1 ). Thus, the overall $59 \%$ of obtained isolates of CNSs were sensitive, while $41 \%$ were resistant to oxacillin (Fig. 4).

S. haemolyticus being the most dominant species among the isolated human-associated Staphylococci, showed MIC value ranging from $<0.5-4 \mu \mathrm{g} / \mathrm{mL}$. Overall, $40 \%$ of $S$. haemolyticus (i.e., 2 out of 5 ) were methicillin (oxacillin) resistant. Among animal-associated, 50\% isolates of S. xylosus with MIC value ranging from < 0.5$1 \mu \mathrm{g} / \mathrm{mL}$ showed resistance to oxacillin (Table 1 ).

In CLAR facility, overall, 22 out of 33 CNSs i.e., 67\% were methicillin resistant CNS (MR-CNS). Among these
22 isolates, 2 showed high resistance i.e., $\geq 16 \mu \mathrm{g} / \mathrm{mL}$. Among the most dominated animal associated CNSs, $S$. xylosus showed varying MIC value ranging from < $0.5 \mu \mathrm{g} / \mathrm{mL}$ to as high as $32 \mu \mathrm{g} / \mathrm{mL}$. Moreover, $\sim 67 \%(8 /$ 12) of $S$. xylosus isolates were methicillin resistant. Furthermore, $100 \%$ (total 5) isolates of S. hominis which was dominating species among human associated staphylococci, were oxacillin resistant with MIC value < $1-8 \mu \mathrm{g} / \mathrm{mL}$ (Table 1 ). Out of two $S$. aureus isolates one (i.e., 50\%) was resistant to oxacillin with MIC value $8 \mu \mathrm{g} /$ $\mathrm{mL}$ (Table 1).

Thus, similar to previous reports in literature [27, 28], this study also confirmed the $>40 \%$ prevalence of methicillin resistant Staphylococci in studied environment.

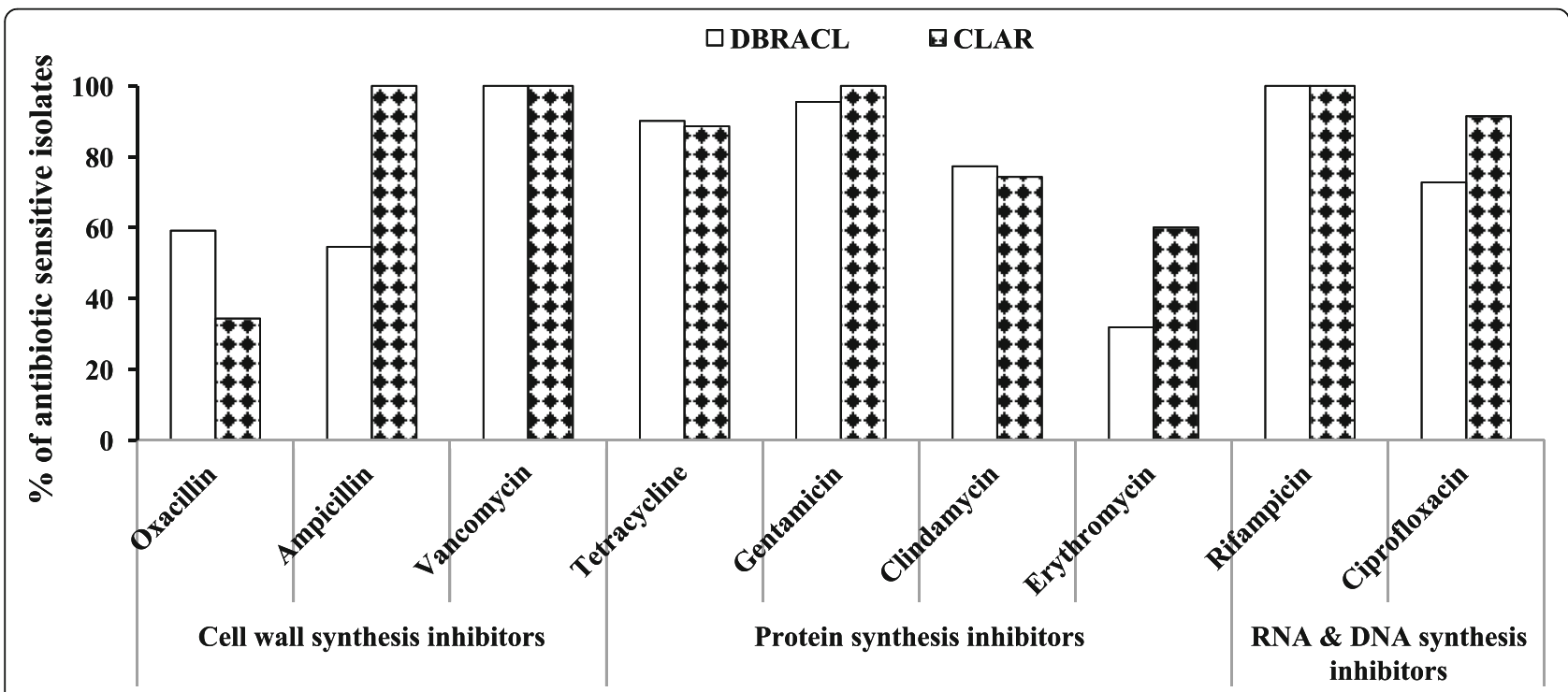

Fig. 4 Overall sensitivity pattern of Staphylococci isolated from the bioaerosols collected at University DBRACL and CLAR against different classes of antibiotics 
The mecA gene encoding for methicillin resistance in $S$. aureus has been widely distributed in CNS species, as demonstrated in previous studies from both India and abroad [29-31]. Therefore, further the occurrence of $m e c A$ gene was identified in all the CNS isolates obtained from two sites using mecA specific primers as described elsewhere [32]. However, in DBRACL, only one isolate was found $m e c A$ positive while in CLAR, none of the MR-CNS isolates harbored the mecA gene.

\section{Anti-biograms of airborne Staphylococci from indoor environments}

Further the antibiotic-susceptibility spectrum of each Staphylococci isolate was determined against 9 different antibacterial agents from different classes (e.g., inhibitors of cell wall synthesis, protein synthesis, nucleic acid synthesis) including, oxacillin, vancomycin, tetracycline, ciprofloxacin, clindamycin, ampicillin, erythromycin, gentamicin and rifampicin (Fig. 4). Here, the proportion of resistant isolates is cumulative of resistant and intermediate value.

The MIC value of vancomycin and rifampicin against all the staphylococcal isolates obtained from both DBRACL and CLAR air was below their susceptibility breakpoints (CLSI guidelines 2009), indicating, 100\% airborne CNS isolates were sensitive to these two last resort anti-MRSA agents (Fig. 4) [33]. The second most efficacious antibiotic was gentamicin for which 95 and $100 \%$ isolates from DBRACL and CLAR, respectively were sensitive. The third most active antibiotic was tetracycline, against which 90 and $89 \%$ isolates from DBRACL and CLAR, respectively were sensitive. Similarly, 72\% DBRACL isolates and 91\% CLAR isolates were ciprofloxacin sensitive. Furthermore, 77 and $74 \%$ clindamycin sensitivity was observed among environmental isolates from DBRACL and CLAR, respectively.

These isolates showed the highest resistance to erythromycin and oxacillin. For example 68\% DBRACL isolates, $40 \%$ of CLAR isolates were erythromycin resistant. Likewise, 41 and $66 \%$ of CNS isolates were oxacillin resistant in DBRACL and CLAR, indoor air, respectively. In contrast to oxacillin, CNS isolates were more susceptible towards ampicillin with 45 and $0 \%$ ampicillin resistant isolates detected from DBRACL and CLAR facilities, respectively. This may be due to the discontinuity of ampicillin usage in the clinical settings, thereby reducing the rate of evolution of ampicillin resistant mutants in the absence of antibiotic in environment. However, approximately $90.9 \%$ isolates from DBRACL (i.e., 20/22) were either resistant or intermediate to the one or more antibiotics.

Overall, these airborne staphylococcal isolates showed resistance to the most common and frequently used conventional antibiotics such as oxacillin and erythromycin.

\section{Multidrug resistance profile of airborne Staphylococci}

So far, oxacillin has not been the effective antibiotic since most of the isolates were resistant to it. Next, multidrug resistance profile of each isolate from both DBRACL and CLAR aerosols was analyzed. MIC value of all the multidrug resistant (resistant to $\geq 2$ drugs) staphylococcal strains belonging to different species are presented in Table 2 and Table 3 for DBRACL and CLAR samples, respectively.

In DBRACL, approximately $73 \%$ staphylococcal isolates (i.e., 16/22) showed resistance to two or more antibiotics (Table 2), majority of the isolates were resistant to erythromycin followed by oxacillin and ampicillin. Particularly, the multidrug resistance pattern was exhibited by six species; S. haemolyticus, S. cohnii, S. hominis, S. epidermidis, S. xylosus, and S. lentus. Notably, some isolates of $S$. haemolyticus were resistant to five antibiotics.

Of note, all the isolates belonging to some of the staphylococcal species from library indoor air such as $S$. cohnii, S. epidermidis, S. xylosus and S. lentus, showed multi-drug resistance.

While in CLAR facility, there were at least 17 isolates out of 35 (i.e., $48.57 \%$ ) belonging to different Staphylococcus species, which were resistant to two or more drugs. Moreover, two isolates of S. xylosus, all the three isolates of $S$. sciuri and one isolate of $S$. capitis were resistant to four antimicrobial drugs. Overall, 5 out of 12 (i.e., $41.67 \%$ ) isolates of S. xylosus, 3 out of 5 (i.e., 60\%) isolates of $S$. hominis, 1 out of 4 (i.e., 25\%) isolate of $S$. capitis and $S$. epidermidis exhibited multi-drug resistant pattern, while, all the strains (i.e., 100\%) of S. lentus and $S$. sciuri showed multi-drug resistance. Furthermore, 6 of total 12 animal associated Staphylococci isolates showed resistance to both erythromycin and clindamycin (Table 3).

\section{Discussion}

Indoor air quality is getting deteriorated due to the microbiological contamination of bioaerosols, which could expose the inhabitants, particularly those with compromised immunity are at high risk due to potential airborne pathogens.

Staphylococcus is one of the dominant genera among indoor airborne microbiomes both in hospital and other residential buildings $[21,34]$. The spread of multidrug resistant Staphylococci in environment from different sources has already been reported in India [30, 35-37]. Furthermore, Staphylococci species such as MRSA and MR-CNSs are the biggest contributors in the spread of antibiotic resistant genes (ARGs) in the environment as reported from India and as well as from abroad $[3-5,9,38]$. CNSs are the common microflora of human skin, however, they can be pathogenic and virulent if they colonizes the open wounds. Of 
Table 2 MIC of antibiotics against Staphylococcal isolates of those species, which showed multidrug resistance in the DBRACL

\begin{tabular}{|c|c|c|c|c|c|c|c|c|c|}
\hline \multirow[t]{3}{*}{ Staphylococci isolates } & & \multirow{3}{*}{$\begin{array}{l}\text { Strain } \\
\text { ID }\end{array}$} & \multicolumn{7}{|c|}{ Antibiotics $^{a}$} \\
\hline & & & \multicolumn{7}{|c|}{ Minimum inhibitory concentrations $(\mu \mathrm{g} / \mathrm{mL})$} \\
\hline & & & Oxa & Tet & Ery & Clin & Cip & Amp & Genta \\
\hline \multirow[t]{10}{*}{ Human associated } & S. haemolyticus & S24 & $1(\mathrm{R})$ & $\leq 0.5(\mathrm{~S})$ & $>32(\mathrm{R})$ & $<0.0625(\mathrm{~S})$ & $0.5(\mathrm{~S})$ & $0.5(\mathrm{R})$ & $<0.0625(\mathrm{~S})$ \\
\hline & & S41 & $0.25(\mathrm{~S})$ & $16(\mathrm{R})$ & $32(\mathrm{R})$ & $4(\mathrm{R})$ & $>32(\mathrm{R})$ & $8(R)$ & $0.25(S)$ \\
\hline & & S43 & $0.5(\mathrm{R})$ & $\leq 0.5(\mathrm{~S})$ & $0.25(\mathrm{~S})$ & $4(\mathrm{R})$ & $0.5(\mathrm{~S})$ & $0.25(\mathrm{~S})$ & $0.125(S)$ \\
\hline & & S53 & $4(\mathrm{R})$ & $16(\mathrm{R})$ & $0.5(S)$ & $4(\mathrm{R})$ & $0.5(S)$ & $>32(\mathrm{R})$ & $<0.5(\mathrm{~S})$ \\
\hline & S. cohnii & S6 & $0.5(\mathrm{R})$ & $\leq 0.5(\mathrm{~S})$ & $>32(\mathrm{R})$ & $>32(\mathrm{R})$ & $1(S)$ & $0.25(\mathrm{~S})$ & $<0.5(\mathrm{~S})$ \\
\hline & & S14 & $0.25(\mathrm{~S})$ & $\leq 0.5(\mathrm{~S})$ & $64(\mathrm{R})$ & $>32(\mathrm{R})$ & $0.5(\mathrm{~S})$ & $0.25(S)$ & $<0.0625(\mathrm{~S})$ \\
\hline & & $\mathrm{S} 22$ & $0.5(\mathrm{R})$ & $\leq 0.5(\mathrm{~S})$ & $8(\mathrm{R})$ & $0.25(\mathrm{~S})$ & $32(\mathrm{R})$ & $1(\mathrm{R})$ & $<0.0625(\mathrm{~S})$ \\
\hline & S. hominis & $\mathrm{S} 21$ & $0.125(S)$ & $\leq 0.5(\mathrm{~S})$ & $32(\mathrm{R})$ & $<0.0625(\mathrm{~S})$ & $1(S)$ & $0.25(\mathrm{~S})$ & $16(\mathrm{R})$ \\
\hline & & $\mathrm{S} 45$ & $16(\mathrm{R})$ & $\leq 0.5(\mathrm{~S})$ & $8(\mathrm{R})$ & $<0.0625(\mathrm{~S})$ & $>32(\mathrm{R}))$ & $0.5(\mathrm{R})$ & $<0.5(\mathrm{~S})$ \\
\hline & S. epidermidis & S52 & $0.25(\mathrm{~S})$ & $\leq 0.5(\mathrm{~S})$ & $>32(\mathrm{R})$ & $<0.0625(\mathrm{~S})$ & $0.25(\mathrm{~S})$ & $4(\mathrm{R})$ & $<0.5(\mathrm{~S})$ \\
\hline \multirow[t]{6}{*}{ Animal associated } & S. xylosus & S17 & $0.5(\mathrm{R})$ & $\leq 0.5(\mathrm{~S})$ & $>32(\mathrm{R})$ & $<0.0625(\mathrm{~S})$ & $0.25(\mathrm{~S})$ & $0.125(\mathrm{~S})$ & $<0.5(\mathrm{~S})$ \\
\hline & & S27 & $0.125(S)$ & $\leq 0.5(\mathrm{~S})$ & $32(\mathrm{R})$ & $<0.0625$ (S) & $1(S)$ & $8(\mathrm{R})$ & $0.5(\mathrm{~S})$ \\
\hline & & S37 & $0.125(S)$ & $\leq 0.5(\mathrm{~S})$ & $8(\mathrm{R})$ & $<0.0625(\mathrm{~S})$ & $0.25(\mathrm{~S})$ & $2(\mathrm{R})$ & $1(S)$ \\
\hline & & S47 & $2(\mathrm{R})$ & $\leq 0.5(\mathrm{~S})$ & $1(\mathrm{I})$ & $<0.0625(\mathrm{~S})$ & $>32$ (R) & $16(\mathrm{R})$ & $0.125(\mathrm{~S})$ \\
\hline & S. lentus & $\mathrm{S} 15$ & $0.5(\mathrm{R})$ & $\leq 0.5(\mathrm{~S})$ & $0.25(\mathrm{~S})$ & $0.25(\mathrm{~S})$ & $>32(\mathrm{R})$ & $0.25(S)$ & $0.0625(\mathrm{~S})$ \\
\hline & & S49 & $0.25(\mathrm{~S})$ & $\leq 0.5(\mathrm{~S})$ & $>32$ (R) & $0.125(S)$ & $0.25(\mathrm{~S})$ & $0.5(\mathrm{R})$ & $<0.0625(\mathrm{~S})$ \\
\hline
\end{tabular}

${ }^{a}$ Oxa Oxacillin, Tet Tetracycline, Ery Erythromycin, Clin Clindamycin, Cip Ciprofloxacin, Amp Ampicillin, Genta Gentamicin, S Sensitive, I Intermediate, $R$ Resistant

Table 3 MIC of seven antibiotics against Staphylococcal isolates of those species which showed multidrug resistance in CLAR

\begin{tabular}{|c|c|c|c|c|c|c|c|c|c|}
\hline \multirow[t]{3}{*}{ Staphylococci isolates } & & \multirow[t]{3}{*}{ Strain ID } & \multicolumn{7}{|c|}{ Antibiotics $^{a}$} \\
\hline & & & \multicolumn{7}{|c|}{ Minimum inhibitory concentrations ( $\mu \mathrm{g} / \mathrm{mL})$} \\
\hline & & & Oxa & Tet & Ery & Clin & Cip & Ceph & Amo \\
\hline \multirow[t]{12}{*}{ Animal associated } & S. xylosus & AHOTR13 & $32(\mathrm{R})$ & $0.5(S)$ & $2(\mathrm{I})$ & $0.5(S)$ & $0.25(\mathrm{~S})$ & $4(1)$ & $0.25(S)$ \\
\hline & & AHRR2 & $0.25(\mathrm{~S})$ & $0.25(S)$ & $0.13(S)$ & $4(R)$ & $0.5(S)$ & $0.03(\mathrm{~S})$ & $0.5(\mathrm{I})$ \\
\hline & & AHRBR4 & $8(\mathrm{R})$ & $32(\mathrm{R})$ & $0.13(\mathrm{~S})$ & $0.5(\mathrm{~S})$ & $0.5(S)$ & $4(1)$ & $0.25(\mathrm{~S})$ \\
\hline & & AHCRNS7 & $1(\mathrm{R})$ & $32(\mathrm{R})$ & $4(\mathrm{l})$ & $0.5(\mathrm{~S})$ & $0.25(\mathrm{~S})$ & $4(1)$ & $0.25(S)$ \\
\hline & & AHWR4 & $1(\mathrm{R})$ & $0.5(S)$ & $32(\mathrm{R})$ & $1(\mathrm{I})$ & $0.25(\mathrm{~S})$ & $2(S)$ & $0.5(\mathrm{I})$ \\
\hline & S. lentus & AHCRNS2 & $<0.5(\mathrm{~S})$ & $0.5(\mathrm{~S})$ & $0.25(\mathrm{~S})$ & $1(\mathrm{l})$ & $0.25(\mathrm{~S})$ & $4(1)$ & $0.06(S)$ \\
\hline & & AHCRNS3 & $<0.5(\mathrm{~S})$ & $0.5(\mathrm{~S})$ & $0.25(\mathrm{~S})$ & $1(\mathrm{I})$ & $0.25(\mathrm{~S})$ & $4(1)$ & $0.06(S)$ \\
\hline & & AHCRNS20 & $<0.5(\mathrm{~S})$ & $0.5(S)$ & $1(\mathrm{I})$ & $1(\mathrm{I})$ & $0.25(\mathrm{~S})$ & $0.5(S)$ & $0.03(S)$ \\
\hline & & AHCRNS21 & $1(\mathrm{R})$ & $0.5(S)$ & $4(1)$ & $1(\mathrm{I})$ & $0.25(\mathrm{~S})$ & $0.25(\mathrm{~S})$ & $0.03(S)$ \\
\hline & S. sciuri & AHRR1 & $1(\mathrm{R})$ & $0.5(S)$ & $2(\mathrm{I})$ & $4(R)$ & $4(R)$ & $0.03(\mathrm{~S})$ & $0.25(S)$ \\
\hline & & AHCRNS10 & $1(\mathrm{R})$ & $8(\mathrm{l})$ & $2(I)$ & $2(1)$ & $1(S)$ & $1(S)$ & $0.13(S)$ \\
\hline & & AHWR3 & $1(\mathrm{R})$ & $0.5(\mathrm{~S})$ & $32(\mathrm{R})$ & $1(\mathrm{I})$ & $0.25(\mathrm{~S})$ & $2(S)$ & $0.5(\mathrm{I})$ \\
\hline \multirow[t]{5}{*}{ Human associated } & S. hominis & AHCRNO5 & $1(\mathrm{R})$ & $1(S)$ & $4(1)$ & $0.06(S)$ & $0.25(\mathrm{~S})$ & $4(1)$ & $0.25(S)$ \\
\hline & & AHCRNO11 & $4(R)$ & $2(S)$ & $1(\mathrm{I})$ & $0.25(S)$ & $1(S)$ & $1(S)$ & $0.25(S)$ \\
\hline & & AHWR6 & $8(R)$ & $0.5(\mathrm{~S})$ & $2(I)$ & $0.25(\mathrm{~S})$ & $1(S)$ & $1(S)$ & $0.25(\mathrm{~S})$ \\
\hline & S. capitis & AHCRNS12 & $1(\mathrm{R})$ & $8(\mathrm{l})$ & $1(\mathrm{I})$ & $0.13(S)$ & $2(1)$ & $1(S)$ & $0.25(\mathrm{~S})$ \\
\hline & S. epidermidis & AHMBR4 & $8(R)$ & $4(S)$ & $1(\mathrm{I})$ & $0.25(\mathrm{~S})$ & $0.06(S)$ & $0.13(\mathrm{~S})$ & $0.5(\mathrm{I})$ \\
\hline
\end{tabular}


late, MR-CNSs are commonly prevalent in indoor/outdoor environments of hospitals and communities [13, 39, 40].

Apart from frequently associated with nosocomial infections, these infectious agents are also of great concern in a variety of indoor environments such as libraries, offices and other residential indoors [10, 34]. Although, we have adequate knowledge of MRSA epidemiology and its role in spreading antimicrobial resistance (AMR) in the environment, there is comparatively scant knowledge of MR-CNS epidemiology in indoor bioaerosols and its AMR pattern in India, which is imperative to evaluate the indoor air quality $[9,11,21,22,41]$. Lately, multidrug resistant CNSs have been dominating in all kinds of microbiomes whether it is environmental samples, hospital-wastes, poultry, agricultural farms etc., thereby they are equally clinically relevant $[15,36,42]$. Recent study in India based on bioaerosols also showed the abundance of methicilin resistant Staphylococci in residential buildings in central India [37]. Yadav et al., have studied the abundance of bacterial and fungal loads in different residential indoor environments near and far from the Gwalior trade fair site [30]. They showed the higher presence of MR-CNS in bioaerosols from trade fair ground, compared to non-fair sites during the fair event [30]. Exploring the microbial contamination of indoor bioaerosols in libraries and experimental areas, where students spend a significant time would be very relevant from their health's perspective [41]. Therefore, the present study was focused on the evaluation of the prevalence of Staphylococci in the indoor air of the University central library (DBRACL) and animal research facility (CLAR), followed by their species characterization and antibiotic sensitivity screening.

In DBRACL, we recorded as much as $6757 \mathrm{CFU} / \mathrm{m}^{2}$ / $\mathrm{hr}$, which was the highest concentration of airborne bacteria including staphylococci from the reading room during monsoon season (Fig. 1a and b), perhaps due to the optimal growth conditions for microorganisms are present during this time. Reasonably, the reading room was highly dense, compared to 3rd floor, 4th floor and 5th floor study areas, which are dedicated to a specific study area (see material and methods). Furthermore, we observed that the numbers of GPB were always higher than the number of GNB (Fig. 1b), indicating that the GPB were predominantly present in the DBRACL air. These findings are similar to the previous report by $\mathrm{Di}$ Giulio et al., where GPB was detected in majority in the indoor bioaerosols of a university of Italy [41]. Of note, air sampling from DBRACL reading room using the settle plate method gives an idea of viable microbial contaminants in the dust, which can deposit over the frequently touched surfaces and may cause potential human health implications after coming into contact [43].
Subsequently, we isolated 22 Staphylococci strains from DBRACL reading room. Most striking observation was that all the 22 Staphylococci strains isolated from DBRACL indoors were identified as CNSs (Fig. 3a and Table 1). Furthermore, 16 out of the 22 were humanassociated CNSs, suggesting that humans are the likely source of airborne Staphylococci in the library, which is quite reasonable as only the students and university staff are permitted in the library. Furthermore, S. haemolyticus was the most prevalent human-associated CNS, followed by $S$. cohnii and S. hominis, among airborne Staphylococci from library indoors. Similar to this observation, previously also $S$. haemolyticus had been found the most frequently isolated CNS in hospital environments, after S. epidermidis from the clinical samples, and is a newly emerging aetiological agent of infectious diseases [13, 40]. Based on the oxacillin MIC value, $41 \%$ of airborne Staphylococci were methicillin resistant-CNS (MR-CNS). Of late, the CNS has been frequently implicated in HAIs as well as in the community acquired infections (CAIs) in Indian continent [36, 44]. Further, antibiotic resistance profiling of these airborne CNSs from DBRACL indoors demonstrated 50\% of Staphylococci were ampicillin resistant, $73 \%$ were erythromycin resistant, 27\% were ciprofloxacin resistant, $23 \%$ were clindamycin resistant, 9\% were tetracycline resistant and $5 \%$ were gentamicin resistant. Our study demonstrated $73 \%$ of CNSs were resistance to more than two antibiotics from DBRACL indoor bioaerosols. Moreover, CNSs are the frequent cause of Staphylococcal infections both in human and animals, and they tend more to develop multi-drug resistance $[19,45]$.

Using the active sampling in CLAR facility, we evaluated an inhalable exposure of humans and animals to microbial contamination, where we observed an unacceptable exposure ( $\geq 1100$ to as much as $6360 \mathrm{CFU} /$ $\mathrm{m}^{3}$ ) of total airborne bacteria at all the indoor locations of animal facility (Fig. 2a). Likewise, the Staphylococci load was also high at most of the indoor locations of the animal facility of university (Fig. 2b). Nevertheless, similar to the library, a predominance of CNS species was observed in the animal facility of the university. Out of total 35 isolates of Staphylococci from CLAR indoors, 33 were CNSs, which were classified into 8 different species (Fig. 3b). As expected, in contrast to the DBRACL, the majority (54\%) of CNS species from CLAR were animalassociated, these were; S. xylosus (12/33), S. lentus (4/33) and $S$. sciuri (3/33). While, human associated Staphylococci species from CLAR were, S. hominis, S. capitis, $S$. epidermidis and S. aureus. Notably, S. xyloxus was the most frequently found animal associated Staphylococci species from CLAR, which is also commonly reported in the genital tract of rabbit and in various other animals such as mouse, rat, chicken and swine [46, 47]. Whereas 
S. hominis was the dominant species among humanassociated Staphylococci from CLAR indoors. The animal associated species $S$. lentus and $S$. sciuri are also the inhabitant of mouse, rat, swine and chicken [47]. Since, CLAR has laboratory animals (mice, rat and rabbit) for experimental purposes; they may be the most likely source of these dominating animal-associated Staphylococci in there indoors.

Further, the presence of $\sim 66 \%$ of CNS species were MR-CNS (Fig. 4) and 49\% of CNS species were multidrug resistant (MDR) in the indoor air of CLAR. S. xylosus being the highest prevalent airborne bacteria in CLAR, showed resistance to a wide variety of antimicrobial drugs used in this study. A similar multi-drug resistance pattern of $S$. xylosus isolates from chicken barn bioaerosols was reported elsewhere [48]. Furthermore, all the isolates of $S$. lentus and $S$. sciuri showed multidrug resistance pattern. Moreover, isolates from 6 CNS species out of total 8 different CNS species obtained were resistant to the two or more drugs, which were characterized as multi-drug resistant (Table 3). Our study is supporting the previous reports about the predominance of CNS species in environmental samples, and their increasing resistance to the existing conventional antibiotics [19, 40, 45].

These MDR Staphylococci were found to be resistant to the conventional antibiotics such as erythromycin, clindamycin, tetracycline and ciprofloxacin. On the contrary, the old and abandoned beta-lactam antibiotic ampicillin was found to be very effective, which may be because of the absence of any selective pressure due to its decreasing use.

A recent study by May et al. showed increased rates of resistance to oxacillin and high rates of multidrug resistance among CNS species from USA over the past decade [49]. Out of total 57 CNSs (22 from library and 35 from CLAR), mecA gene was detected in only one MR-CNS strain (identified as S. hominis) from the library, which showed a high MIC $(16 \mu \mathrm{g} / \mathrm{mL})$ of oxacillin. Out of total airborne MR-CNSs, we only found 2 strains with MIC > $8 \mu \mathrm{g} / \mathrm{mL}$, one strain with oxacillin MIC of $16 \mu \mathrm{g} / \mathrm{mL}$ from DBRACL, which was also detected as mecA positive, and another with oxacillin MIC of $32 \mu \mathrm{g} / \mathrm{mL}$ from CLAR, which was mecA negative. Thus, resistance in the $m e c A$ negative MR-CNSs might be due to some other mechanisms; 1) overproduction of the beta-lactamase, which inactivates the oxacillin $[50,51], 2)$ secretion of modified penicillin binding protein (PBP) with reduced affinity to beta-lactam drugs [52], 3) increase in the PBP expression [53]. Mostly, these airborne $\operatorname{mec} A$ negative MR-CNS strains may be categorized in the borderline methicillin resistance phenotype, which exhibits lowlevel of oxacillin resistance with MIC value $<8 \mu \mathrm{g} / \mathrm{mL}$. However, in this study we used only single PCR method to identify the mecA gene, therefore, the absence of other mec type genes in these isolated airborne MR-CNSs could not be excluded. Instead, the use of multiplex PCR as previously described [54] is required to fully identify all SCCmec type genes which will be pursued in future.

A similar non-linkage between mecA genotype and methicillin resistance phenotype has also been reported previously both in MR-CNS [50] and MRSA strains [55]. The ability of CNS to act as reservoir for resistance genes and to transfer them into other pathogens such as $S$. aureus is other important dimension to the problem of antibiotic resistance. As shown previously that the bacteria obtained from animals and animal dwelling places are the major cause for the spreading of pathogens to other animals as well as humans [38]. Moreover, Staphylococci species are the rapidly emerging threat to human health, particularly CNSs are largely implicated in skin and soft tissue infections (SSTIs) such as in patients with burns and have undergone surgeries $[12,20]$. CNS species frequently found responsible for infecting wounds and medical implants inside a hospital include: Staphylococcus capiti, Staphylococcus haemolyticus, Staphylococcus epidermidis, Staphylococcus lugdunensis, Staphylococcus hominis, Staphylococcus saprophyticus, Staphylococcus simulans and Staphylococcus auricularis $[39,56]$.

This study also recommends that the exposure of workers and students in CLAR to such a high concentration of Staphylococci $\left(5866 \mathrm{CFU} / \mathrm{m}^{3}\right.$ ) beyond the acceptable limit of microbial exposure as described in WHO guidelines [57], should not be undermined, as this SKC based active collection method captures the inhalable particulate matter $\left(\mathrm{PM}_{2.5}\right)$ with up to $90 \%$ efficiency. However, the actual level of microbial contamination is likely to be higher in CLAR if the bioaerosols containing larger size particulate matters including $\mathrm{PM}_{10}$ and agglomerates were examined. The larger size bioaerosols can also settle down on the external body surfaces resulting in the colonization of the skin and soft tissues and particularly vulnerable for cuts and wounds. Evidently, some of the CNS species such as S. epidermidis, S. hominis and S. hemolyticus etc., detected here from both the sites (Fig. 3a-b) have already been implicated in SSTIs [56], these may cause potential health risks in humans having open wounds or may also alter the results in animal studies where surgeries are employed.

On the other hand, the settle plate method only reflects the bacterial burden in large dust particles including agglomerates, therefore, an estimation of inhalable exposure of humans in the library to microbial contaminants was not possible. At the same time this passive sampling gives us a risk assessment of the contaminated air if it deposits onto a crucial surfaces such as wounds/ cuts or on the frequently used items in the library environment such as books, mobiles, laptops etc. $[43,56]$. 


\section{Conclusions}

Overall, this study identified that both the facilities contained an unacceptable airborne Staphylococcal loads with a huge proportion of MR-CNS and MDR-CNS, which could affect human health, especially people with compromised immunity. Most notably, a majority of the airborne MR-CNS identified in this study may be categorized under low-level methicillin resistance phenotype. However, the major limitation of this study is the use of two different sampling methods, for which the bacterial burden could not be directly compared between two sites. Nevertheless, this study provided an efficient estimation of airborne staphylococcal species diversity and their antibiogram in the indoor environments, which might be helpful in deciding the strategy for the successful eradication of MDR-CNSs.

\section{Methods}

\section{Description of sampling sites}

Dr. B.R. Ambedkar central library (DBRACL) of Jawaharlal Nehru University

Bioaerosols sampling to evaluate bacterial load in indoor environment was carried out in DBRACL of Jawaharlal Nehru University. It is a 40 year old, nine storied building situated in the central part of the campus where thousands of students studying every day and night. The building comprises of a huge reading hall on the ground floor and other eight floors with books arranged in different sections based on subjects. Along with the main reading hall (ground floor), three other sections namely, Science section (3rd floor), European language section (4th floor) and Afro-Asian language section (5th floor) were selected randomly for the air sampling as they have similar pattern of book storage.

\section{Central laboratory animal resources (CLAR) of Jawaharlal Nehru University}

The air sampling was carried out during monsoon in the CLAR facility of Jawaharlal Nehru University, New Delhi, India. CLAR is a two-storied building, situated in the south corner of the campus. It comprises of three different areas viz., the animal rooms (rat breeding room, mice breeding room, operation theatre and rabbit room), corridors and washing area. This building has heating ventilating and air conditioning (HVAC) ventilation system. CLAR has limited human interference except for the staff and visiting research students for laboratory experiments.

\section{Air sampling by the settle plate technique}

In DBRACL, air samplings were done in the first week of pre-monsoon (May), monsoon (July) and postmonsoon (September) in 2015 by settle plate technique using non-selective nutrient rich Brain heart infusion
(BHI) media. $9 \mathrm{~cm}$ petriplate containing appropriate growth medium was exposed to air with open lid by keeping it at $1-1.5 \mathrm{~m}$ above the ground for $1 \mathrm{hr}$. Cycloheximide $(0.2 \mathrm{mg} / \mathrm{mL})$ was added in the media to inhibit the fungal growth [43]. Relative humidity (RH) and temperature were also recorded with the help of Mextech TM-1 Thermo Hygro digital clock (Mextech technologies, India) at the time of sampling. Relative humidity varied from 30.30 to $39 \%, 36.66$ to $63 \%$ and 38 to $51 \%$ during pre-monsoon, monsoon and postmonsoon, respectively. The temperature varied from $27.9{ }^{\circ} \mathrm{C}$ to $33.1^{\circ} \mathrm{C}, 28.6^{\circ} \mathrm{C}$ to $30.7^{\circ} \mathrm{C}$ and $27^{\circ} \mathrm{C}$ to $31.5^{\circ} \mathrm{C}$ during pre-monsoon, monsoon and post-monsoon, respectively. While the wind speed was still in the reading room indoor due to fully air-conditioned, it was approximately $0.5 \mathrm{mph}$, while rest of the locations were naturally ventilated. The sampling was also carried out in the outdoor air around the library, the climatic conditions for the same have been included in Table 4.

All equipment and materials were handled aseptically to ensure that the samples were not contaminated. After bioaerosols collection, plates were transferred to the lab (which is at $5 \mathrm{~min}$ distance from the sampling site) on ice in a UV sterile carbon box, followed by incubation at $37^{\circ} \mathrm{C}$ for $48 \mathrm{~h}$ for bacterial colony growth.

\section{Active sampling using SKC biosampler}

In CLAR facility, air samples were collected during monsoon in July 2015 by using SKC biosampler (Cat. 2259594, SKC, UK) at the flow rate of $12.5 \mathrm{~L} / \mathrm{min}$ for $30 \mathrm{~min}$ (recommended sampling time by the manufacturer for water based collecting liquids) in $20 \mathrm{ml}$ of $10 \mathrm{mM}$ phosphate buffer saline (PBS) (pH 7.4). This SKC biosampler, resembles an All-glass Impinger (AGI-30), collection efficiency is close to $100 \%$ over a wide range of particle sizes when operated at $12.5 \mathrm{~L} / \mathrm{min}$ with water and liquid of similar viscosity. For particle $<1.0 \mu \mathrm{m}$ diameter, collection efficiency decreased to approximately $90 \%$ at $0.5 \mu \mathrm{m}$. Thus, this SKC based active collection method captures the inhalable particulate matter $\left(\mathrm{PM}_{2.5}\right)$ with $100 \%$ efficiency [58]. Temperature and $\mathrm{RH}$ were also recorded during air sampling (Table 4). Temperature varied from $21.5^{\circ} \mathrm{C}$ to $26.8^{\circ} \mathrm{C}$ while $\mathrm{RH}$ varied from 41 to $91 \%$. All equipment and materials were sterilized before sampling to ensure that the collected air samples were not contaminated.

After sampling, $0.1 \mathrm{~mL}$ aliquots and their 10 fold dilutions were spread onto BHI agar plate for total airborne bacterial enumeration and onto mannitol salt agar (MSA) plate for airborne Staphylococci counting. MSA was used in order to differentiate CPS and CNS [59].

\section{Enumeration and isolation of bacterial colonies}

The bacterial loads obtained on $9 \mathrm{~cm}$ petri plate exposed for $1 \mathrm{hr}$, were expressed as $\mathrm{CFU} / \mathrm{m}^{2} / \mathrm{hr}$ [43]. After 
Table 4 Climatic conditions at DBRACL and CLAR during air sampling in 2015

\begin{tabular}{|c|c|c|c|c|c|c|c|c|}
\hline \multirow{2}{*}{$\begin{array}{l}\text { Sampling } \\
\text { site }\end{array}$} & \multirow[t]{2}{*}{ Sampling place } & \multicolumn{2}{|c|}{ Pre-monsoon (May) } & \multicolumn{2}{|c|}{ Monsoon (July) } & \multicolumn{2}{|c|}{ Post-monsoon (September) } & \multirow{2}{*}{$\begin{array}{l}\text { Type of } \\
\text { ventilation }\end{array}$} \\
\hline & & $\begin{array}{l}\text { Temperature } \\
\left({ }^{\circ} \mathrm{C}\right)\end{array}$ & $\begin{array}{l}\text { Relative } \\
\text { humidity (\%) }\end{array}$ & $\begin{array}{l}\text { Temperature } \\
\left({ }^{\circ} \mathrm{C}\right)\end{array}$ & $\begin{array}{l}\text { Relative } \\
\text { humidity (\%) }\end{array}$ & $\begin{array}{l}\text { Temperature } \\
\left({ }^{\circ} \mathrm{C}\right)\end{array}$ & $\begin{array}{l}\text { Relative } \\
\text { humidity (\%) }\end{array}$ & \\
\hline \multirow[t]{5}{*}{ DBRACL } & Reading room & 28.5 & 31.3 & 28.6 & 36.7 & 27 & 38 & HVAC \\
\hline & Third floor & 27.9 & 39 & 29.4 & 59 & 30 & 42 & Natural \\
\hline & Fourth floor & 29.4 & 30.3 & 29.7 & 58 & 29.6 & 46 & Natural \\
\hline & Fifth floor & 30.7 & 30.6 & 29.5 & 58 & 29.7 & 51 & Natural \\
\hline & Outdoor & 33.1 & 34 & 30.7 & 63 & 31.5 & 38 & Natural \\
\hline \multirow[t]{7}{*}{ CLAR } & Rat Breeding room & \multirow{7}{*}{\multicolumn{2}{|c|}{$\begin{array}{l}\text { Not } \\
\text { collected }\end{array}$}} & 25.6 & 41 & \multirow{7}{*}{\multicolumn{2}{|c|}{$\begin{array}{l}\text { Not } \\
\text { collected }\end{array}$}} & HVAC \\
\hline & Mice Breeding room & & & 24.8 & 42 & & & HVAC \\
\hline & Rabbit room & & & 21.5 & 65 & & & HVAC \\
\hline & Washing place & & & 26.8 & 90 & & & Natural \\
\hline & O.T room & & & 23.7 & 73 & & & HVAC \\
\hline & $\begin{array}{l}\text { Corridor near source } \\
\text { area }\end{array}$ & & & 23.3 & 44 & & & HVAC \\
\hline & Corridor near office & & & 25.9 & 91 & & & Natural \\
\hline
\end{tabular}

Footnote: Heating, ventilating and air conditioning (HVAC)

incubation, plates were counted for total culturable bacteria and then refrigerated at $4{ }^{\circ} \mathrm{C}$ until further analyses. For characterization of bacteria, we transferred each colony aseptically from primary plate to secondary plates containing a selective medium, for example Eosin methylene blue (EMB) for isolation of GNB, Sheep Blood agar (BA) media plates for GPB and MSA for Staphylococci. All the media were purchased from HiMedia, India. After secondary plating in these selective media, plates were incubated for $24 \mathrm{hr}$ at $37^{\circ} \mathrm{C}$. Total GPB, GNB and staphylococci were counted after the 48 hr incubation.

\section{Characterization of Staphylococci}

Bacterial colonies grown on MSA plate were further processed for colony morphology by Gram staining, followed by biochemical tests such as catalase test, MSA test, coagulase test, and staphylo monotec test kit plus (Fluka, Sigma-Aldrich) for confirmatory test of S. aureus. Oxidase test (Sigma-Aldrich) was done for CNS. Staphylococcus species showed as Gram positive cocci in clusters under microscope after Gram staining. In MSA test $S$. aureus ferments mannitol, lowering down the $\mathrm{pH}$ of the media, phenol red indicator turns yellow and thus formed yellow colored colonies on MSA agar plate whereas CNS colonies were pink in color on MSA plates [60]. S. aureus were further characterized based on their colony morphology using Gram staining, followed by confirmatory biochemical tests such as oxidase test, catalase test, coagulase test and staphylo-monotec test (Fluka, Sigma-Aldrich). Staphylococci show negative result for oxidase test. There are certain bacteria, which have ability to produce colored compound indophenol blue from the oxidation of N, N-dimethyl-p-phenylenediamine oxalate and $\alpha$-naphthol in the presence of the enzyme cytochrome oxidase. For oxidase test, bacterial smear was spread over oxidase disc containing $\mathrm{N}, \mathrm{N}$ dimethyl-p-phenylenediamine oxalate and which were found to be negative as it does not change the color of the disc [60]. Catalase is an antioxidant enzyme that is produced by aerobic microbes in order to neutralize toxic hydrogen peroxide $\left(\mathrm{H}_{2} \mathrm{O}_{2}\right.$; an oxygen metabolite). This enzyme decomposes the $\mathrm{H}_{2} \mathrm{O}_{2}$ to water and oxygen and thus resulting in rapid oxygen bubble production. For catalase test $3 \% \mathrm{H}_{2} \mathrm{O}_{2}$ was applied on bacterial smear and immediate oxygen bubbling was produced. Staphylococci give positive catalase test. Coagulase test is used to differentiate $S$. aureus from CNS. S. aureus produces coagulase enzyme which converts soluble fibrinogen to insoluble fibrin present in plasma, thus agglutinating the blood cells. Coagulase tests were performed using coagulase plasma from rabbit (HiMedia, India). S. aureus gives positive coagulase test. Further, monotec test was performed to differentiate between S. aureus and other Staphylococci species of CPS class. S. aureus gives positive monotec test. StaphyloMonotec test kit plus (Fluka, Sigma-Aldrich) was used for this purpose. The test reagent consists of monodisperse particles, which are coated with fibrinogen and immunoglobulin G (IgG). S. aureus has protein A in its cell wall. Fibrinogen binds to the coagulase which is a cell associated enzyme, and the Fc part of immunoglobulin G binds to protein A. When $S$. aureus is mixed with the Staphylomonotec test reagent, a rapid agglutination occurs as a result of binding of fibrinogen to coagulase enzyme and IgG to protein A. After identification, bacterial isolates were stored in $30 \%$ glycerol at $-80^{\circ} \mathrm{C}$ for further analyses. 
Finally, from the air of the reading room of the library, after repeated sub-culturing on MSA plates and subsequently confirmed by API staph kit, we could identify total 22 Staphylococci strains.

In a similar fashion after active sampling from CLAR, 35 colonies from MSA plates were confirmed as Staphylococci strains.

\section{Antibiotic susceptibility testing of staphylococcal isolates}

Antibiotic susceptibility of all the airborne staphylococcal isolates were determined by measuring minimum inhibitory concentration (MIC) in cation adjusted-Mueller Hinton Broth (MHB) by broth micro-dilution method according to the Clinical Laboratory Standard Institute guideline [26]. The MIC is defined as the lowest drug concentration preventing visible turbidity after $24 \mathrm{~h}$ of incubation at $37{ }^{\circ} \mathrm{C}$. A final concentration of inoculums of $10^{5} \mathrm{CFU} / \mathrm{mL}$ concentration of bacterial culture was used to determine MICs. We determined the MICs of oxacillin against all collected staphylococcal isolates. $S$. aureus ATCC 33591, S. aureus ATCC 29213 and S. epidermidis ATCC 35984 were used as reference strains during determination of MICs, as well as during each confirmatory biochemical tests. The MIC breakpoints of oxacillin against $S$. aureus are $\geq 4$ and $\leq 2 \mu \mathrm{g} / \mathrm{mL}$ for resistant and susceptible strains, respectively. Against CNS, MIC breakpoints of oxacillin are $\geq 0.5$ and $\leq$ $0.25 \mu \mathrm{g} / \mathrm{mL}$ for resistant and susceptible strains, respectively [26]. The group of CNS isolates which showed susceptibility and resistance to oxacillin, were considered as MS-CNS and MR-CNS, respectively and were further tested against eight antibiotics of different class, these are vancomycin, tetracycline, rifampicin, ciprofloxacin, clindamycin, ampicillin, erythromycin and gentamicin. The multidrug resistance in bacteria is defined when an organism is resistant to at least two classes of antibiotics [61]. Susceptibility breakpoint for each antibiotic was followed as per CLSI guidelines [26].

\section{Species level identification of environmental Staphylococci isolates}

All the staphylococci isolates including both CPS and CNS were further identified at species level by commercial identification system API-staph test kit (BioMerieux, France) [25], according to manufacturer's guidelines. Briefly, purified staphylococci isolates were grown on BHI agar for 18$24 \mathrm{hr}$, a homogeneous mixture of each isolate was prepared by suspending colonies in staph-medium (provided with the kit) with turbidity corresponding to 0.5 Macfarland standard. This suspension was used to fill the microtubes of API-strips, followed by strip incubation at $37^{\circ} \mathrm{C}$ for 24 hr. After incubation, the color change was monitored and was compared to negative control. Appropriate reagents were added as required for particular reaction as described in the kit manual. Finally, the species assignment was done using API software (APIweb ${ }^{\text {th }}$ API Staph V4.1).

Furthermore, to identify the source of airborne staphylococci contamination, a multiplex PCR of staphylococcal thermonuclease (nuc) gene targeting all human associated staphylococci species, i.e., S. aureus, $S$. capitis, S. caprae, S. epidermidis, S. haemolyticus, S. hominis, S. lugdunensis, S. saprophyticus, and S. warneri was also performed, using the primers and PCR conditions as described previously [24].

\section{PCR based identification of mecA gene encoding for oxacillin resistance}

The identification of $m e c A$ gene encoding for methicillin resistance in Staphylococcus species was done by PCR. The PCR reaction mixture was prepared by adding and mixing $2 \mu \mathrm{L}$ template DNA $1 \mu \mathrm{L}$ each primer $(m e c A)$ forward and reverse as described elsewhere [32], $2 \mu \mathrm{L}$ each deoxynucleotide triphosphate ( $2.5 \mathrm{mM} \mathrm{dNTP}), 2.5 \mu \mathrm{L} 10 \mathrm{X}$ Ex Taq buffer, and $0.5 \mu \mathrm{L}$ Ex Taq polymerase (Takara Co., Ltd., Kyoto, Japan), in a final volume of $25 \mu \mathrm{L}$. A PCR thermal cycler was used for the final amplification of the PCR product. The reaction was set for amplification, with an initial denaturation step $\left(95^{\circ} \mathrm{C}, 3 \mathrm{~min}\right)$; 30 cycles of denaturation $\left(95^{\circ} \mathrm{C}, 30 \mathrm{~s}\right)$, annealing $\left(47^{\circ} \mathrm{C}, 45 \mathrm{~s}\right)$, and extension $\left(72^{\circ} \mathrm{C}, 30 \mathrm{~s}\right)$; and a final elongation step at $72^{\circ} \mathrm{C}$ for 5 min. PCR products were visualized by electrophoresis in $1 \mathrm{X}$ Tris-acetate-EDTA on a $1 \%$ agarose gel stained with ethidium bromide. S. aureus ATCC 33591 and S. aureus ATCC 29213 was used as $m e c A$ positive and negative control, respectively.

\section{Abbreviations}

DBRACL: Dr. B.R. Ambedkar central library; CLAR: Central laboratory animal resources; MIC: Minimum inhibitory concentration; MRS: Methicillin resistant Staphylococci; CFU: Colony forming unit; CPS: Coagulase positive Staphylococci; CNS: Coagulase negative Staphylococci; GPB: Gram positive bacteria; GNB: Gram negative bacteria; MRSA: Methicillin resistant Staphylococcus aureus; MS-CNS: Methicillin sensitive- coagulase negative Staphylococci; MR-CNS: Methicillin resistant- coagulase negative Staphylococci; MDR-CNS: Multidrug resistant- coagulase negative Staphylococci; SSTIs: Skin and soft tissue infections; EMB: Eosin methylene blue; MSA: Mannitol salt agar; BA: Blood agar; BHI: Brain heart infusion; MHB: Mueller Hinton broth; HVAC: Heating, ventilation and air conditioning

\section{Acknowledgements}

HK is thankful to University Grant Commission (UGC) for research fellowship and contingency. MKC is thankful to Council of Scientific and Industrial Research (CSIR) for his research fellowship and contingency. MS is thankful to DST-WOSA for the research grant. KM is grateful to UGC-UPE (II), DST-PURSE and DST-SERB for financial support to this study. We also acknowledge Dr. B.R. Ambedkar Central Library (DBRACL) and Central Laboratory Animal Resources (CLAR) facility, Jawaharlal Nehru University (JNU), New Delhi, for their cooperation in air sampling.

\section{Authors' contributions}

MS and KM conceived and designed the study, analysed data and wrote the manuscript. HK performed experiments and wrote the manuscript. TC collected bioaerosol samples; TC, HK and MKC did initial screening of the collected microbes. All authors reviewed and commented on the manuscript. The author(s) read and approved the final manuscript. 


\section{Funding}

This study was supported by financial grants from University Grants Commission (UGC-UPE-II: ID 59, JNU) and Department of Science and Technology (DST-PURSE (PAC-JNU-DST-PURSE-462 (Phase II) and DST-SERB (DST-SERB-EMR/2016/001708)) to KM, and a DST-WOSA research grant (SR/ WOS-A/LS-36/2018 (G)) to MS. Funding bodies have no role in the design of the study and collection, analysis, and interpretation of data and in writing the manuscript.

\section{Availability of data and materials}

The datasets used and/or analysed during the current study are available from the corresponding author on reasonable request.

\section{Ethics approval and consent to participate}

Not applicable.

\section{Consent for publication}

Not applicable.

\section{Competing interests}

The authors declare that they have no competing interests.

Received: 30 October 2019 Accepted: 25 June 2020

Published online: 16 July 2020

\section{References}

1. Cyprowski M, Ławniczek-Wałczyk A, Gołofit-Szymczak M, Frączek K, Kozdrój J, Górny RL. Bacterial aerosols in a municipal landfill environment. Sci Tota Environ. 2019;660:288-96.

2. Stephens B. What have we learned about the microbiomes of indoor environments? mSystems. 2016;1:e00083-16.

3. Agodi A, Auxilia F, Barchitta M, Cristina ML, D'Alessandro D, Mura I, Nobile M, Pasquarella C, Avondo S, Bellocchi P. Operating theatre ventilation systems and microbial air contamination in total joint replacement surgery: results of the GISIO-ISChIA study. J Hosp Infect. 2015;90:213-9.

4. Létourneau V, Nehmé B, Mériaux A, Massé D, Cormier Y, Duchaine C. Human pathogens and tetracycline-resistant bacteria in bioaerosols of swine confinement buildings and in nasal flora of hog producers. Int J Hyg Env Heal. 2010;213:444-9.

5. Solomon FB, Wadilo FW, Arota AA, Abraham YL. Antibiotic resistant airborne bacteria and their multidrug resistance pattern at University teaching referral Hospital in South Ethiopia. Ann Clin Microb Anti. 2017;16:29.

6. Haque M, Sartelli M, McKimm J, Bakar MA. Health care-associated infections-an overview. Infect Drug Resist. 2018;11:2321-33.

7. Morawska L, Ayoko GA, Bae GN, Buonanno G, Chao CYH, Clifford S, Fu SC, Hänninen $\mathrm{O}, \mathrm{He} \mathrm{C}$, Isaxon C. Airborne particles in indoor environment of homes, schools, offices and aged care facilities: the main routes of exposure. Environ Int. 2017;108:75-83.

8. Lipsitch M, Singer RS, Levin BR. Antibiotics in agriculture: when is it time to close the barn door? Proc Natl Acad Sci. USA. 2002;99:5752-4.

9. Wang Y, Wang C, Song L. Distribution of antibiotic resistance genes and bacteria from six atmospheric environments: exposure risk to human. Sc Total Environ. 2019;694:133750.

10. Gandara A, Mota LC, Flores C, Perez HR, Green CF, Gibbs SG. Isolation of Staphylococcus aureus and antibiotic-resistant Staphylococcus aureus from residential indoor bioaerosols. Environ Health Perspet. 2006;114:1859-64.

11. Hoseinzadeh E, Samarghandie MR, Ghiasian SA, Alikhani MY, Roshanaie G. Evaluation of bioaerosols in five educational hospitals wards air in Hamedan, during 2011-2012. Jundishapur J Microbiol. 2013;6:e10704.

12. Becker K, Heilmann C, Peters G. Coagulase-negative staphylococci. Clin Microbiol Rev. 2014;27:870-926.

13. Czekaj T, Ciszewski M, Szewczyk EM. Staphylococcus haemolyticus-an emerging threat in the twilight of the antibiotics age. Microbiology. 2015; 161:2061-8.

14. Botelho AMN, das Graça Nunes Z, Asensi MD, MZR G, SEL F, AMS F. Characterization of coagulase-negative staphylococci isolated from hospital indoor air and a comparative analysis between airborne and inpatient isolates of Staphylococcus epidermidis. J Med Microbiol. 2012;61:1136-45.

15. Berlak N, Shany E, Ben-Shimol S, Chertok IA, Goldinger G, Greenberg D, Melamed R. Late onset sepsis: comparison between coagulase-negative staphylococci and other bacteria in the neonatal intensive care unit. Infect Dis. 2018;50:764-70.

16. Khare R, Kothari T, Castagnaro J, Hemmings B, Tso M, Juretschko S. Active monitoring and feedback to improve blood culture fill volumes and positivity across a large integrated health system. Clin Infect Dis. 2019;70: 262-8.

17. Chen X-P, Li W-G, Zheng H, Du H-Y, Zhang L, Zhang L, Che J, Wu Y, Liu S $\mathrm{M}, \mathrm{Lu}$ J-X. Extreme diversity and multiple SCC mec elements in coagulasenegative Staphylococcus found in the clinic and Community in Beijing. China Ann Clin Microb Anti. 2017;16:57.

18. John JF, Harvin AM. History and evolution of antibiotic resistance in coagulase-negative staphylococci: susceptibility profiles of new antistaphylococcal agents. Ther Clin Risk Manag. 2007;3:1143-52.

19. Klibi A, Maaroufi A, Torres C, Jouini A. Detection and characterization of methicillin-resistant and susceptible coagulase-negative staphylococci in milk from cows with clinical mastitis in Tunisia. Int J Ant Ag. 2018;52:930-5.

20. Latif M, Usman J, Gilani M, Munir T, Mushtaq M, Anjum R. Coagulase negative staphylococci-a fast emerging threat. J Pak Med Assoc. 2015;65: 283-6.

21. Moon KW, Huh EH, Jeong HC. Seasonal evaluation of bioaerosols from indoor air of residential apartments within the metropolitan area in South Korea. Environ Monit Assess. 2014;186:2111-20.

22. Kalwasinska A, Burkowska A, Wilk I. Microbial air contamination in indoor environment of a university library. Ann Agr Env Med. 2012;19:25-9.

23. Tsai FC, Macher JM. Concentrations of airborne culturable bacteria in 100 large US office buildings from the BASE study. Indoor Air. 2005;15:71-81.

24. Hirotaki S, Sasaki T, Kuwahara-Arai K, Hiramatsu K. Rapid and accurate identification of human-associated staphylococci by use of multiplex PCR. J Clin Microbiol. 2011:49:3627-31.

25. Sampimon OC, Zadoks RN, De Vliegher S, Supré K, Haesebrouck F, Barkema HW, Sol J, Lam TJGM. Performance of API staph ID 32 and staph-Zym for identification of coagulase-negative staphylococci isolated from bovine milk samples. Vet Microbiol. 2009;136:300-5.

26. Wayne PA. Clinical and laboratory standards institute. Performance standards for antimicrobial susceptibility testing 2011.

27. Chambers HF, DeLeo FR. Waves of resistance: Staphylococcus aureus in the antibiotic era. Nat Rev Microbiol. 2009;7:629-41.

28. Kobayashi T, Nakaminami H, Ohtani H, Yamada K, Nasu Y, Takadama S, Noguchi N, Fujii T, Matsumoto T. An outbreak of severe infectious diseases caused by methicillin-resistant Staphylococcus aureus USA300 clone among hospitalized patients and nursing staff in a tertiary care university hospital. J Infect Chemother. 2019;26:76-81.

29. Kern A, Perreten V. Clinical and molecular features of methicillin-resistant, coagulase-negative staphylococci of pets and horses. J Antimicrob Chemoth. 2013:68:1256-66.

30. Yadav J, Kumar A, Mahor P, Goel AK, Chaudhary HS, Yadava PK, Yadav H, Kumar P. Distribution of airborne microbes and antibiotic susceptibility pattern of bacteria during Gwalior trade fair, Central India. J Formos Med Assoc. 2015;114:639-46.

31. Saber H, Jasni AS, Jamaluddin TZMT, Ibrahim R. A review of staphylococcal cassette chromosome mec (SCCmec) types in coagulase-negative staphylococci (CoNS) species. Malays J Med Sci. 2017;24:7-18.

32. Jonas D, Speck M, Daschner FD, Grundmann H. Rapid PCR-based identification of methicillin-resistant Staphylococcus aureus from screening swabs. J Clin Microbiol. 2002:40:1821-3.

33. McKenna M. Antibiotic resistance: the last resort. Nature. 2013;499:394-6.

34. Faridi S, Hassanvand MS, Naddafi K, Yunesian M, Nabizadeh R, Sowlat MH, Kashani H, Gholampour A, Niazi S, Zare A. Indoor/outdoor relationships of bioaerosol concentrations in a retirement home and a school dormitory. Environ Sci Pollut R. 2015:22:8190-200.

35. Bouchiat C, El-Zeenni N, Chakrakodi B, Nagaraj S, Arakere G, Etienne J. Epidemiology of Staphylococcus aureus in Bangalore, India: emergence of the ST217 clone and high rate of resistance to erythromycin and ciprofloxacin in the community. New Microbes New Infect. 2015;7:15-20.

36. Kumar D, Pornsukarom S, Sivaraman GK, Thakur S. Environmental dissemination of multidrug methicillin-resistant Staphylococcus sciuri after application of manure from commercial swine production systems. Foodborne Pathog Dis. 2018;15:210-7.

37. Kumar P, Goel AK. Prevalence of methicillin resistant staphylococcal bioaerosols in and around residential houses in an urban area in Centra India. J Pathog. 2016;2016:7163615. 
38. Allen HK, Donato J, Wang HH, Cloud-Hansen KA, Davies J, Handelsman J. Call of the wild: antibiotic resistance genes in natural environments. Nat Rev Microbiol. 2010;8:251-9.

39. Becker K, Both A, Weißelberg S, Heilmann C, Rohde H. Emergence of coagulase-negative staphylococci. Expert Rev Anti-Infect Ther. 2020;18:349-66.

40. Dziri R, Klibi N, Lozano C, Said LB, Bellaaj R, Tenorio C, Boudabous A, Slama KB, Torres C. High prevalence of Staphylococcus haemolyticus and Staphylococcus saprophyticus in environmental samples of a Tunisian hospital. Diag Micr Infec Dis. 2016;85:136-40.

41. Di Giulio M, Grande R, Di Campli E, Di Bartolomeo S, Cellini L. Indoor air quality in university environments. Environ Monit Assess. 2010;170:509-17.

42. Sudharsanam S, Mathias S, Barani R, Sugumar M, Janardhanan J, Annamalai $R$, Swaminathan S, Srikanth P. Fate of airborne coagulase negative staphylococci. Int J Infect Dis. 2012;16:e385.

43. Napoli C, Marcotrigiano V, Montagna MT. Air sampling procedures to evaluate microbial contamination: a comparison between active and passive methods in operating theatres. BMC Public Health. 2012;12:594.

44. Mir BA. Srikanth. Prevalence and antimicrobial susceptibility of methicillin resistant Staphylococcus aureus and coagulase-negative staphylococci in a tertiary care hospital. Asian J Pharm Clin Res. 2013;6:231-4.

45. Pyörälä S, Taponen S. Coagulase-negative staphylococci-emerging mastitis pathogens. Vet Microbiol. 2009;134:3-8.

46. Jacques M, Olson ME, Crichlow AM, Osborne AD, Costerton JW. The normal microflora of the female rabbit's genital tract. Can J Vet Res. 1986;50:272-4.

47. Rueanghiran C, Viriyarampa S, Thongyuan S, Tulayakul P. Species diversity and antimicrobial susceptibility properties of Staphylococcus isolated from broiler feces in selected farms, Thailand. J Public Health. 2017;47:44-55.

48. Vela J, Hildebrandt K, Metcalfe A, Rempel H, Bittman S, Topp E, Diarra M. Characterization of Staphylococcus xylosus isolated from broiler chicken barn bioaerosol. Poultry Sci. 2012;91:3003-12.

49. May L, Klein EY, Rothman RE, Laxminarayan R. Trends in antibiotic resistance in coagulase-negative staphylococci in the United States, 1999 to 2012. Antimicrob Agents Ch. 2014;58:1404-9.

50. Argudín MA, Roisin S, Nienhaus L, Dodemont M, De Mendonça R, Nonhoff C, Deplano A, Denis O. Genetic diversity among Staphylococcus aureus isolates showing oxacillin and/or cefoxitin resistance not linked to the presence of mec genes. Antimicrob Agents Ch. 2018;62:e00091-18.

51. Martins A. de Lourdes Rs Cunha M. methicillin resistance in Staphylococcus aureus and coagulase-negative staphylococci: epidemiological and molecular aspects. Microbiol Immunol. 2007:51:787-95.

52. Kotsakis SD, Tzouvelekis LS, Zerva L, Liakopoulos A, Petinaki E. Staphylococcus lugdunensis strain with a modified PBP1A/1B expressing resistance to $\beta$-lactams. Euro J Clin Microbiol. 2012;31:169-72.

53. Yoshida R, Kuwahara-Arai K, Baba T, Cui L, Richardson JF, Hiramatsu K. Physiological and molecular analysis of a mecA-negative Staphylococcus aureus clinical strain that expresses heterogeneous methicillin resistance. J Antimicrob Chemoth. 2003;51:247-55.

54. Zhang K, McClure J-A, Conly JM. Enhanced multiplex PCR assay for typing of staphylococcal cassette chromosome mec types I to $\mathrm{V}$ in methicillinresistant Staphylococcus aureus. Mol Cell Probes. 2012;26:218-21.

55. Maalej SM, Rhimi FM, Fines M, Mnif B, Leclercq R, Hammami A. Analysis of borderline oxacillin-resistant Staphylococcus aureus (BORSA) strains isolated in Tunisia. J Clin Microbiol. 2012;50:3345-8.

56. Natsis NE, Cohen PR. Coagulase-negative Staphylococcus skin and soft tissue infections. Am J Clin Dermatol. 2018;19:671-7.

57. World Health Organization. Regional Office for Europe \& Parker, M.T. Hospitalacquired infections: guidelines to laboratory methods. World Health Organization. Regional Office for Europe. 1978. https://apps.who.int/iris/ handle/10665/272697.

58. Macher JM, Macher JM. Evaluation of bioaerosol sampler performance. Appl Occup Environ Hyg. 1997;12:730-6.

59. Bowers KM, Wren MWD, Shetty NP. Screening for methicillin resistance in Staphylococcus aureus and coagulase-negative staphylococci: an evaluation of three selective media and Mastalex-MRSA latex agglutination. Brit J Biomed Sci. 2003;60:71-4.

60. Cowan ST. Cowan and Steel's manual for the identification of medical bacteria: Cambridge university press; 2004.

61. Magiorakos AP, Srinivasan A, Carey RB, Carmeli Y, Falagas ME, Giske CG, Harbarth S, Hindler JF, Kahlmeter G, Olsson-Liljequist B, et al. Multidrugresistant, extensively drug-resistant and pandrug-resistant bacteria: an international expert proposal for interim standard definitions for acquired resistance. Clin Microbiol Infect. 2012;18:268-81. https://doi.org/10.1111/j. 1469-0691.2011.03570.x.

\section{Publisher's Note}

Springer Nature remains neutral with regard to jurisdictional claims in published maps and institutional affiliations.
Ready to submit your research? Choose BMC and benefit from:

- fast, convenient online submission

- thorough peer review by experienced researchers in your field

- rapid publication on acceptance

- support for research data, including large and complex data types

- gold Open Access which fosters wider collaboration and increased citations

- maximum visibility for your research: over $100 \mathrm{M}$ website views per year

At BMC, research is always in progress.

Learn more biomedcentral.com/submissions 